\title{
The C-C Chemokine Receptor CCR3 Participates in Stimulation of Eosinophil Arrest on Inflammatory Endothelium in Shear Flow
}

\author{
Joji Kitayama, ${ }^{\star}$ Charles R. Mackay, ${ }^{\ddagger}$ Paul D. Ponath, ${ }^{\ddagger}$ and Timothy A. Springer* \\ *Center for Blood Research and Department of Pathology, Harvard Medical School, Boston, Massachusetts 02115; and ${ }^{\ddagger}$ LeukoSite, Inc., \\ Cambridge, Massachusetts 02142
}

\begin{abstract}
Chemokines are widely hypothesized to stimulate firm adhesion of leukocytes on endothelium in shear flow. Thus far, this has been demonstrated experimentally for exogenously added chemoattractants, but not for those released by endothelium. We found that human umbilical cord endothelial cells (HUVEC) stimulated with TNF- $\alpha$ and IFN- $\gamma$ secreted eosinophil chemoattractants into the culture supernatant. This material induced transendothelial chemotaxis, stimulated eosinophil binding to purified intercellular adhesion molecule 1, and augmented binding to purified vascular cell adhesion molecule 1 in a 3-min static assay. Chemotaxis and stimulation of adhesion were abrogated completely by the pretreatment of eosinophils with an mAb to the C-C chemokine receptor 3 (CCR3). Eosinophils accumulated efficiently on HUVEC stimulated with TNF- $\alpha$ and IFN- $\gamma$ in shear flow at $1.5 \mathrm{dyn} / \mathrm{cm}^{2}$. CCR3 mAb slightly but significantly reduced eosinophil arrest and accumulation, by preventing development of firm adhesion by some of the tethered eosinophils, so that they detached within $30 \mathrm{~s}$ after the initial tethering. In the presence of $\mathrm{mAb}$ to the $\alpha \mathbf{4}$ integrin subunit, the effect of CCR3 mAb was more prominent, and approximately half of eosinophil arrest and accumulation was abolished. Inhibition by CCR3 $\mathrm{mAb}$ in the presence of $\beta 2$ integrin $\mathrm{mAb}$ was similar to that in control eosinophils. This is the first evidence that endothelial cell-derived chemokines can activate firm adhesion through $\alpha 4$ and $\beta 2$ integrins even in the presence of shear flow. (J. Clin. Invest. 1998. 101:2017-2024.) Key words: endothelium • eosinophils • eotaxin • chemokine receptor • very late antigen 4
\end{abstract}

\section{Introduction}

Leukocyte emigration into inflammatory sites is a multistep process mediated by a series of sequential but partially overlapping interactions $(1,2)$. Tethering and rolling on endothelium are followed by development of firm adhesion, i.e., arrest, and then by diapedesis. It is generally accepted that rolling leukocytes encounter factors that stimulate upregulation of in-

Address correspondence to Timothy A. Springer, Ph.D., The Center for Blood Research and Harvard Medical School, Department of Pathology, 200 Longwood Avenue, Boston, MA 02115. Phone: 617-2783200; FAX: 617-278-3232; E-mail: springer@sprsgi.med.harvard.edu

Received for publication 23 December 1997 and accepted 18 February 1998

J. Clin. Invest.

(C) The American Society for Clinical Investigation, Inc. 0021-9738/98/05/2017/08 \$2.00

Volume 101, Number 9, May 1998, 2017-2024

http://www.jci.org tegrin-dependent adhesion, which is required for arrest and transmigration. Although the exact mechanisms are not clearly understood, chemoattractants locally produced from endothelial or stromal cells have been proposed as a possible mechanism to activate the rolling leukocytes and upregulate integrin function. In flow assays with neutrophils or transfectants, it has been shown that FMLP $(3,4)$ and IL-8 (5) can enhance integrin-mediated adhesion to intercellular adhesion molecule $(\text { ICAM })^{1} 1$ or vascular cell adhesion molecule (VCAM) 1. However, in those studies, the chemoattractants were added exogenously. In vivo, chemoattractants released from the luminal surface of the endothelium would be rapidly diluted and swept downstream by blood flow, and the concentration of chemoattractants that flowing or rolling leukocytes actually encounter may be much lower than when chemokine is added exogenously. Although some chemoattractants have been reported to be retained on the endothelial surface (6), and a chemokine bound to a leukocyte-derived, purified proteoglycan, CD44, can augment leukocyte adhesion in stasis (7), it is still unclear whether membrane-associated chemoattractants can actually stimulate integrin avidity in flow. Eosinophils often predominate in tissues with chronic allergic inflammation, such as reactive airways, allergic rhinitis, or atopic skin reactions $(8,9)$. In contrast to neutrophils that are stimulated mainly by $\mathrm{CXC}$ chemokines such as IL-8 and Gro proteins, eosinophils show chemotaxis and $\mathrm{Ca}^{2+}$ influx responses to C-C chemokines, including RANTES (for regulated upon activation, normal $\mathrm{T}$ cell expressed and secreted) (10-12), macrophage inflammatory protein $1 \alpha(11)$, monocyte chemotactic protein (MCP) 2 (13), MCP-3 (14), MCP-4 (15), and eotaxin (16-20). On eosinophils, RANTES and MCP-3 stimulate transient $\alpha 4 \beta 1$ and prolonged $\beta 2$ integrin avidity in stasis (21). Information on the receptors for chemokines is growing rapidly. Many different $\mathrm{G}$ protein-coupled receptors for $\mathrm{C}-\mathrm{C}$ chemokines and for CXC chemokines have been molecularly characterized $(22,23)$. Mononuclear cells express and respond to multiple chemokine receptors (23-25). Eosinophils but not resting mononuclear cells or neutrophils express the $\mathrm{C}-\mathrm{C}$ chemokine receptor (CCR) 3 (26-28). Furthermore, CCR3 appears to be the predominant chemokine receptor on normodense eosinophils. An mAb to CCR3, 7B11, can inhibit completely eosinophil chemotaxis to RANTES, MCP-2, MCP3 , MCP-4, and eotaxin (28). Using this $\mathrm{mAb}$, we have examined the role of endothelial cell-derived chemokines on eosinophil accumulation and arrest on activated endothelial cells with an in vitro laminar flow assay.

1. Abbreviations used in this paper: $\mathrm{CCR}, \mathrm{C}-\mathrm{C}$ chemokine receptor; CTx, cholera toxin; HUVEC, human umbilical cord endothelial cell(s); ICAM, intercellular adhesion molecule; MCP, monocyte chemotactic protein; PAF, platelet-activating factor; PTx, pertussis toxin; RANTES, regulated upon activation, normal $\mathrm{T}$ cell expressed and secreted; VCAM, vascular cell adhesion molecule. 


\section{Methods}

Reagents and antibodies. Recombinant TNF- $\alpha$, IFN- $\gamma$, and IL-4 were purchased from Genzyme Corp. (Cambridge, MA). mAbs 7B11 to CCR3, and 7D9 to IL-8RA (both mIgG1) were characterized previously $(28,29)$. mAbs HP2/1 to integrin $\alpha 4$ (Amac, Inc., Westbrook, $\mathrm{ME})$ and TS1/18 to integrin $\beta 2$ (30) were used as purified IgG. ICAM-1 was immunopurified on an R6.5 mAb-Sepharose column (31), and the soluble form of VCAM-1 (32) was a generous gift from Dr. R. Lobb (Biogen, Inc., Cambridge, MA). For blocking experiments, the mAbs were added to $10^{6}$ cells suspended in $0.1 \mathrm{ml}$ HBSS

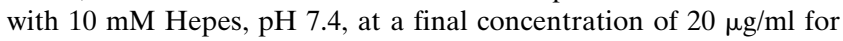
each $\mathrm{mAb}$. After $1 \mathrm{~h}$ incubation on ice, the cells were diluted to $1.0 \mathrm{ml}$ of assay medium (10\% heat-inactivated FCS plus RPMI 1640 for transmigration and static adhesion assay; HBSS with $10 \mathrm{mM}$ Hepes including $2 \mathrm{mM} \mathrm{Ca}^{2+}, 1 \mathrm{mM} \mathrm{Mg}^{2+}$, and $10 \% \mathrm{FCS}, \mathrm{pH} 7.4$, for flow assay) and used for experiments. Pertussis toxin (PTx) and cholera toxin (CTx) were purchased from Calbiochem Corp. (San Diego, CA), and UK-74505 was a gift from Pfizer Ltd. (Sandwich, Kent, UK). Eosinophils were treated with these reagents as described for $\mathrm{mAb}$ above.

Cell purification. Eosinophils were purified from healthy volunteers by negative immunomagnetic selection (33). Briefly, granulocytes were isolated from citrate-anticoagulated whole blood by dextran sedimentation, Ficoll-Hypaque centrifugation, and hypotonic lysis of red blood cells. The cells were washed twice with PBS with $1 \%$ BSA and $5 \mathrm{mM}$ EDTA, and incubated with anti-CD16-conjugated microbeads (MACS; Miltenyi Biotec Inc., Sunnyvale, CA) for $30 \mathrm{~min}$ on ice. The cell suspensions were then applied onto a magnetic column (MACS column), and negative populations were collected. The isolates routinely contained $>99 \%$ eosinophils with viability $>95 \%$ by Trypan blue exclusion.

Preparation of human umbilical vein endothelial cell (HUVEC) monolayer. HUVEC were isolated and cultured in flasks coated with $25 \mu \mathrm{g} / \mathrm{ml}$ fibronectin (Sigma Chemical Co., St. Louis, MO) with medium 199 (M199) supplemented with 15\% FCS (Sigma Chemical Co.), $50 \mu \mathrm{g} / \mathrm{ml}$ endothelial mitogen (Biomedical Technologies, Inc., Stoughton, MA), and $100 \mu \mathrm{g} / \mathrm{ml}$ heparin (Sigma Chemical Co.) (34). Primary or first passage HUVEC were used for all experiments.

Transmigration assay. Confluent HUVEC were cultured in endothelial culture medium with or without optimal concentrations of IL-4 (10 ng/ml), TNF- $\alpha(100 \mathrm{U} / \mathrm{ml})$, and/or IFN- $\gamma(100 \mathrm{U} / \mathrm{ml})$ for $22 \mathrm{~h}$, then the monolayers were washed with RPMI 1640 three times and incubated in $1 \mathrm{ml}$ of $10 \%$ FCS plus RPMI 1640 for another $2 \mathrm{~h}$. The supernatants were collected and kept at $-20^{\circ} \mathrm{C}$ until use. Transendothelial chemotaxis was examined as described previously (35). Briefly, HUVEC were cultured for $1 \mathrm{wk}$ on fibronectin-coated Transwell inserts (6.5 mm diameter, $5 \mu \mathrm{m}$ pore size) (Costar Corp., Cambridge, MA). Inserts were transferred onto lower chambers containing $500 \mu \mathrm{l}$ of the supernatants, eosinophils $\left(2.5 \times 10^{5}\right)$ suspended in $100 \mu \mathrm{l}$ of $10 \%$ FCS plus RPMI 1640 were added to each insert, and the cells that transmigrated to the lower chambers after $1 \mathrm{~h}$ were counted by FACS ${ }^{\circledR}$ as described previously (17).

Static adhesion assay. Purified ICAM-1 or VCAM-1 was diluted to $25 \mu \mathrm{g} / \mathrm{ml}$ in PBS (pH 9.0) and immediately spotted onto wells (35 $\mathrm{mm}$ ) of a six-well culture plate. After $2 \mathrm{~h}$ incubation at $37^{\circ} \mathrm{C}$, the wells were washed twice with RPMI 1640 and blocked with $20 \mu \mathrm{g} / \mathrm{ml} \mathrm{HSA}$ (Calbiochem Corp.) for $24 \mathrm{~h}$ at $4^{\circ} \mathrm{C}$. After washing, $0.5 \mathrm{ml}$ of the HUVEC culture supernatants were added and prewarmed in the $37^{\circ} \mathrm{C}$ incubator for $10 \mathrm{~min}$. Eosinophils $\left(10^{6}\right)$ suspended in $0.5 \mathrm{ml}$ of $10 \%$ FCS plus RPMI 1640 were then added to the well and placed at $37^{\circ} \mathrm{C}$ for 3 min, after which all the cells had settled to the bottom of the well. The wells were then gently washed with $2.0 \mathrm{ml}$ of warmed assay medium five times, and the cells bound to the substrate were counted in three different fields under the microscope.

Laminar flow assay. A parallel-plate flow chamber (36) was mounted on a HUVEC monolayer cultured in a six-well plate $(35 \mathrm{~mm}$ in diameter), placed on the stage of a phase-contrast microscope, and monitored with a $\times 20$ objective $(3,37)$. Wall shear stress was calculated as described previously (3). Eosinophils suspended in $1.0 \mathrm{ml}$ of assay medium were perfused on the HUVEC monolayer for $3 \mathrm{~min}$ through the flow chamber using an automated syringe pump (Harvard Apparatus, Inc., South Natick, MA) attached to the outlet side. In some experiments, the shear flow was increased to 10,20 , and 40 $\mathrm{dyn} / \mathrm{cm}^{2}$ for $10 \mathrm{~s}$ each after $3 \mathrm{~min}$ perfusion at $1.5 \mathrm{dyn} / \mathrm{cm}^{2}$, and cells remaining at the end of each shear were calculated as the percentage of the total number of cells observed just before the increase in shear to $10 \mathrm{dyn} / \mathrm{cm}^{2}$. Cells interacting with the substrate during flow were analyzed with the images videotaped with a video camera (TEC-470 CCD; Optronics, Goleta, CA) and recorder (Hi-8 CVD-1000; Sony Corp., Park Ridge, NJ).

Evaluation of tethering and accumulation, and enumeration of arrested, rolling, and detached cells. Tethered cells were defined as cells that maintained an adhesive interaction with the HUVEC monolayer for at least $1 \mathrm{~s}$. The number of tethers was counted over the initial 1 min after the flow became stable. For the analysis of posttethering behavior, the movement of each tethered cell was observed carefully for another $30 \mathrm{~s}$ after it first tethered on the monolayer. Cells detached in the flow stream in this $30 \mathrm{~s}$ were counted as detached cells. Among the cells that remained adherent in this period, cells that were displaced less than or more than one cell diameter for the $30 \mathrm{~s}$ were defined as arrested and rolling cells, respectively. Total cell accumulation was defined as the number of the cells that arrested at 3 min after the flow became stable. $P$ values were calculated by paired Student's $t$ test, and the differences with $P<0.05$ were considered to be significant.

\section{Results}

HUVEC activated with TNF- $\alpha$ and IFN- $\gamma$ produce chemokines for eosinophils. The culture supernatants of HUVEC were examined for chemotactic activities for purified eosinophils with a transendothelial migration assay (Fig. $1 A$ ). Few eosinophils migrated to assay medium or supernatants of unstimulated or IL-4-stimulated HUVEC. However, significantly more eosinophils transmigrated to supernatants of HUVEC stimulated with $100 \mathrm{U} / \mathrm{ml}$ TNF- $\alpha$ or $100 \mathrm{U} / \mathrm{ml}$ IFN- $\gamma$. The combination of TNF- $\alpha$ and IFN- $\gamma$ produced synergistic effects for eosinophil chemotaxis (Fig. $1 A$ ). Pretreatment with the mAb to CCR3 reduced eosinophil chemotaxis to the supernatant from $\mathrm{TNF}-\alpha$ and IFN- $\gamma$-stimulated HUVEC to the same level as that to control supernatant, whereas mAb to IL-8RA (CXCR1) showed no effect (Fig. $1 B$ ).

Eosinophil binding to immobilized ICAM-1 or VCAM-1 was examined with a 3-min static assay. Supernatants from HUVEC activated with TNF- $\alpha$ and IFN- $\gamma$ increased markedly eosinophil adhesion to ICAM-1 (Fig. 2, left, no mAb). This enhancement of binding to ICAM-1 was blocked almost completely by CCR3 mAb but not by IL-8RA mAb (Fig. 2, left). By contrast to ICAM-1, unstimulated eosinophils showed marked binding to VCAM-1 (Fig. 2, right). However, supernatant from activated HUVEC increased the adhesion to VCAM-1 by approximately twofold (Fig. 2, right, no mAb). Again, this stimulated binding to VCAM-1 was inhibited almost completely by CCR3 mAb (Fig. 2, right).

$C C R 3 \mathrm{mAb}$ partially reduces eosinophil arrest and accumulation on HUVEC activated with TNF- $\alpha$ and IFN- $\gamma$. Accumulation of eosinophils after 3 min perfusion at a wall shear stress of $1.5 \mathrm{dyn} / \mathrm{cm}^{2}$ on activated HUVEC was reduced by $22 \pm 4.7 \%$ by CCR3 mAb (Fig. 3, right). Although inhibition was not as prominent as in static experiments, it was reproducible in all of seven different experiments (6.5-32\% inhibition), and the dif- 
A

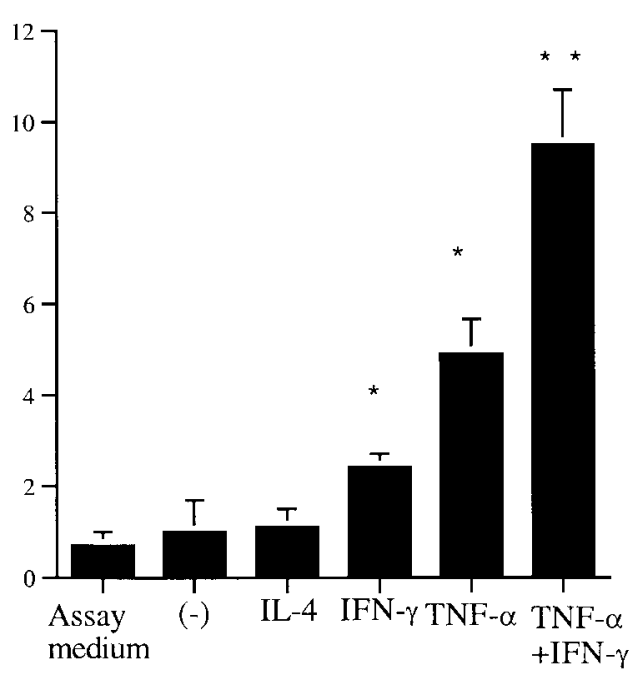

B

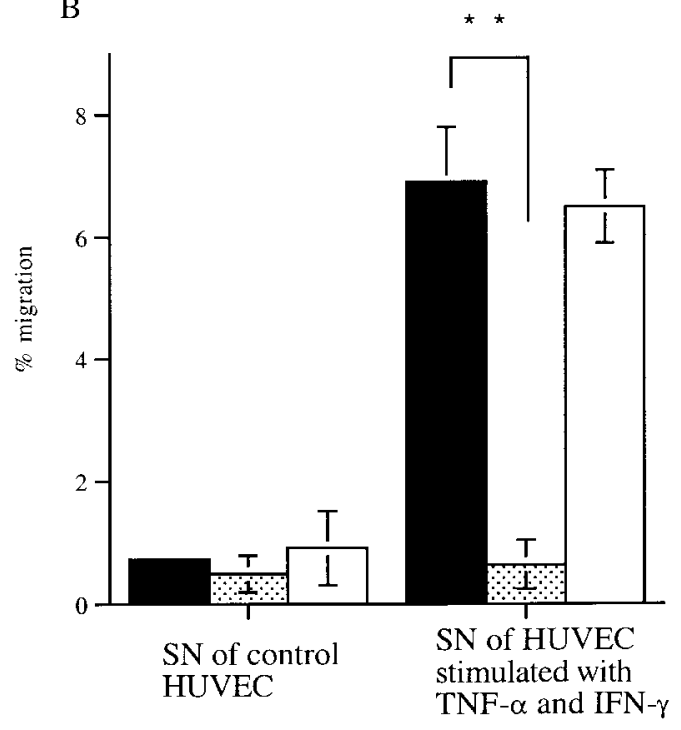

Figure 1. (A) Stimulation of eosinophil chemotaxis by supernatants from cytokine-activated endothelium and inhibition by CCR $3 \mathrm{mAb}$. Eosinophil chemotaxis to culture supernatants $(S N)$ of HUVEC stimulated with various cytokines. Confluent HUVEC were cultured for $22 \mathrm{~h}$ with or without $10 \mathrm{ng} / \mathrm{ml}$ IL-4, $100 \mathrm{U} / \mathrm{ml}$ IFN- $\gamma$, and/or 100 U/ml TNF- $\alpha$. Monolayers were washed and cultured for another $2 \mathrm{~h}$ in $1 \mathrm{ml}$ of $10 \%$ FCS plus RPMI 1640. The supernatants were collected and used as the attractant in the lower chamber of a

transendothelial migration assay; migration was across unstimulated endothelial monolayers. $(B)$ Eosinophils were pretreated with $\mathrm{mAbs}$ to CCR3 (dotted bars) or IL-8RA (white bars) and examined for transmigration toward the supernatants (SN) of HUVEC activated with $100 \mathrm{U} / \mathrm{ml}$ IFN- $\gamma$ and $100 \mathrm{U} / \mathrm{ml}$ TNF- $\alpha$. Black bars, No mAb. Migrated cells were counted by FACS ${ }^{\circledR}$, and the mean \pm SD of three independent experiments is shown. $* P<0.05, * * P<0.01$.

ference was statistically significant $(P<0.005, n=7)$. Cells that interacted with the endothelial monolayer, i.e., tethered, during the first 1-min period were individually monitored and enumerated according to their behavior during the 30 -s period subsequent to tethering as arrested, rolling, or detaching cells (Fig. 3, left). Almost all control eosinophils arrested abruptly shortly after tethering, i.e., without intervening rolling, and few cells detached within the following $30 \mathrm{~s}$. A significantly greater number of CCR3 mAb-treated cells detached $(P<$ $0.01, n=7)$, and the number of arrested cells was decreased significantly, by $20 \pm 5.4 \%(P<0.02, n=7)$. This clearly indicates that the stimulation of CCR3 by HUVEC-derived chemoattractants is at least in part responsible for eosinophil arrest formation in shear flow. However, almost all detachment was observed within $30 \mathrm{~s}$ after the initial tethering and rarely thereafter. Moreover, even in anti-CCR3-treated cells, the majority of the adherent cells still showed immediate arrest, with few rolling cells (Fig. 3, left).

$C C R 3 m A b$ partially blocks both $\alpha 4$ and $\beta 2$ integrin activation. Since eosinophils have been shown to functionally express $\alpha 4$ as well as $\beta 2$ integrins (38-41), we next examined the effect of the anti-CCR3 mAb together with the mAbs to $\alpha 4$ as well as $\beta 2$ integrins. As already described for experiments on TNF- $\alpha$-stimulated HUVEC (42), the $\alpha 4$ integrin mAb HP2/1
Purified ICAM-1

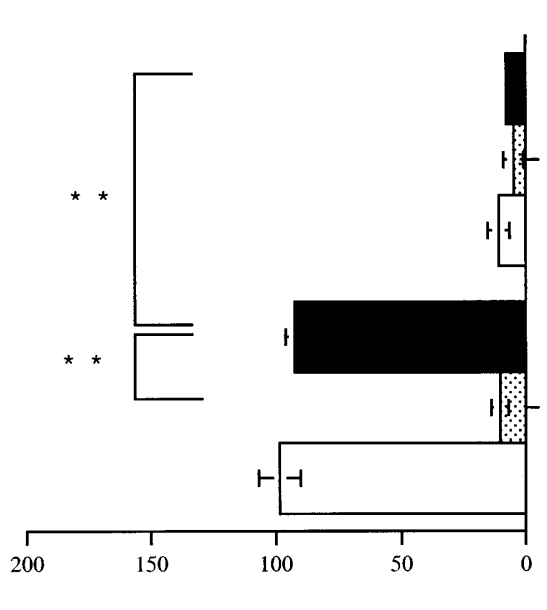

cells bound /field
Purified VCAM-1

$\mathrm{SN}$ of control HUVEC

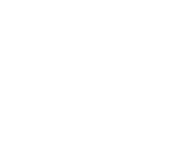

SN of HUVEC stimulated with TNF- $\alpha+$ IFN- $\gamma$

$$
-\gamma
$$$$
0
$$

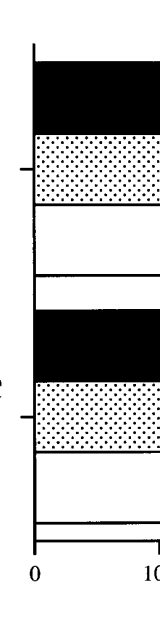
the cells remaining adherent to the substrate were counted in three different fields by microscopic observation. Data show mean \pm SD in three experiments. $* P<0.05, * * P<0.01$.
Figure 2. Stimulation of eosinophil adhesion to ICAM-1 and VCAM-1 by supernatant from TNF- $\alpha$ and IFN- $\gamma$-activated HUVEC and inhibition phils treated with or without (black bars) mAbs to CCR3 (dotted bars) or IL-8RA (white mobilized ICAM-1 or VCAM-1 in the presence of supernatants $(S N)$ from HUVEC with or without activation by $100 \mathrm{U} / \mathrm{ml} \mathrm{IFN}-\gamma$ and TNF- $\alpha$. After static incubation for $3 \mathrm{~min}$, the wells were gently washed, and by CCR3 mAb. Eosinobars) were placed on im- 
Tethers

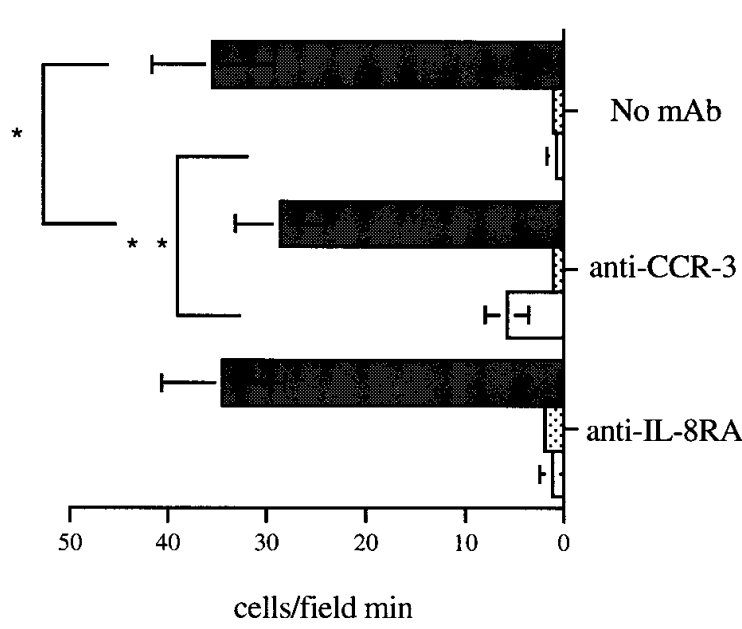

Total accumulation

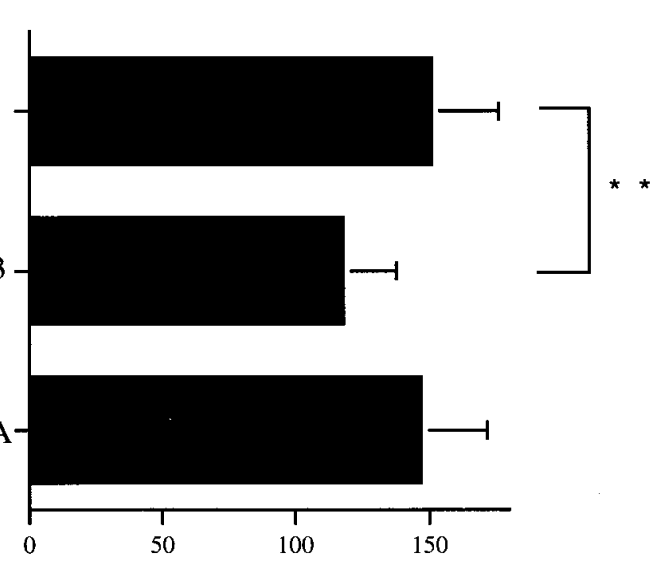

cells/field
Figure 3. Effect of CCR3 $\mathrm{mAb}$ on eosinophil behavior after tethering and accumulation on activated HUVEC. HUVEC monolayers were stimulated with $100 \mathrm{U} / \mathrm{ml}$ of TNF- $\alpha$ and IFN- $\gamma$ for $24 \mathrm{~h}$, and eosinophils treated with each $\mathrm{mAb}$ were resuspended in HBSS with $10 \mathrm{mM}$ Hepes including $2 \mathrm{mM} \mathrm{Ca}^{2+}$, $1 \mathrm{mM} \mathrm{Mg}^{2+}$, and $10 \%$ FCS, pH 7.4, and perfused on the monolayer for $3 \mathrm{~min}$ at $1.5 \mathrm{dyn} / \mathrm{cm}^{2}$. Cells that tethered in the first minute were enumerated for subsequent arrest (gray bars), roll-

ing (dotted bars), or detachment (white bars), and total accumulation was evaluated at 3 min. Data show mean \pm SD in seven independent experiments. $* P<0.05,{ }^{*} P<<0.01$.

partially reduced eosinophil arrest and induced rolling or detachment in approximately half of the tethered eosinophils (Fig. 4, left). This resulted in a $36 \pm 3.7 \%$ decrease in eosinophil accumulation on HUVEC activated with TNF- $\alpha$ and IFN- $\gamma$ $(P<0.05, n=4)$ (Fig. 4, right). However, CCR3 mAb gave additional inhibition, and the effect of CCR3 mAb on $\alpha 4$ integrin-blocked eosinophils was more prominent than on control eosinophils. Compared with treatment with $\alpha 4 \mathrm{mAb}$ alone, addition of CCR3 mAb further decreased eosinophil arrest by $41 \pm 11 \%(P<0.01, n=4)$, increased detachment twofold ( $P<0.05, n=4)$ (Fig. 4, left), and decreased total cell accumulation by $49 \pm 11 \%(P<0.01, n=4)$ (Fig. 4 , right $). \beta 2$ integrin $\mathrm{mAb}$ TS1/18 had little effect on eosinophil accumulation, although treatment with $\alpha 4$ and $\beta 2 \mathrm{mAb}$ together blocked almost completely eosinophil arrest and accumulation. In the presence of $\beta 2$ integrin $\mathrm{mAb}, \mathrm{CCR} 3 \mathrm{mAb}$ partially decreased arrest and increased detachment, and resulted in a $26 \pm 7.0 \%$ reduction in total accumulation $(P<0.05, n=4)$. In

MAbs used for treatment

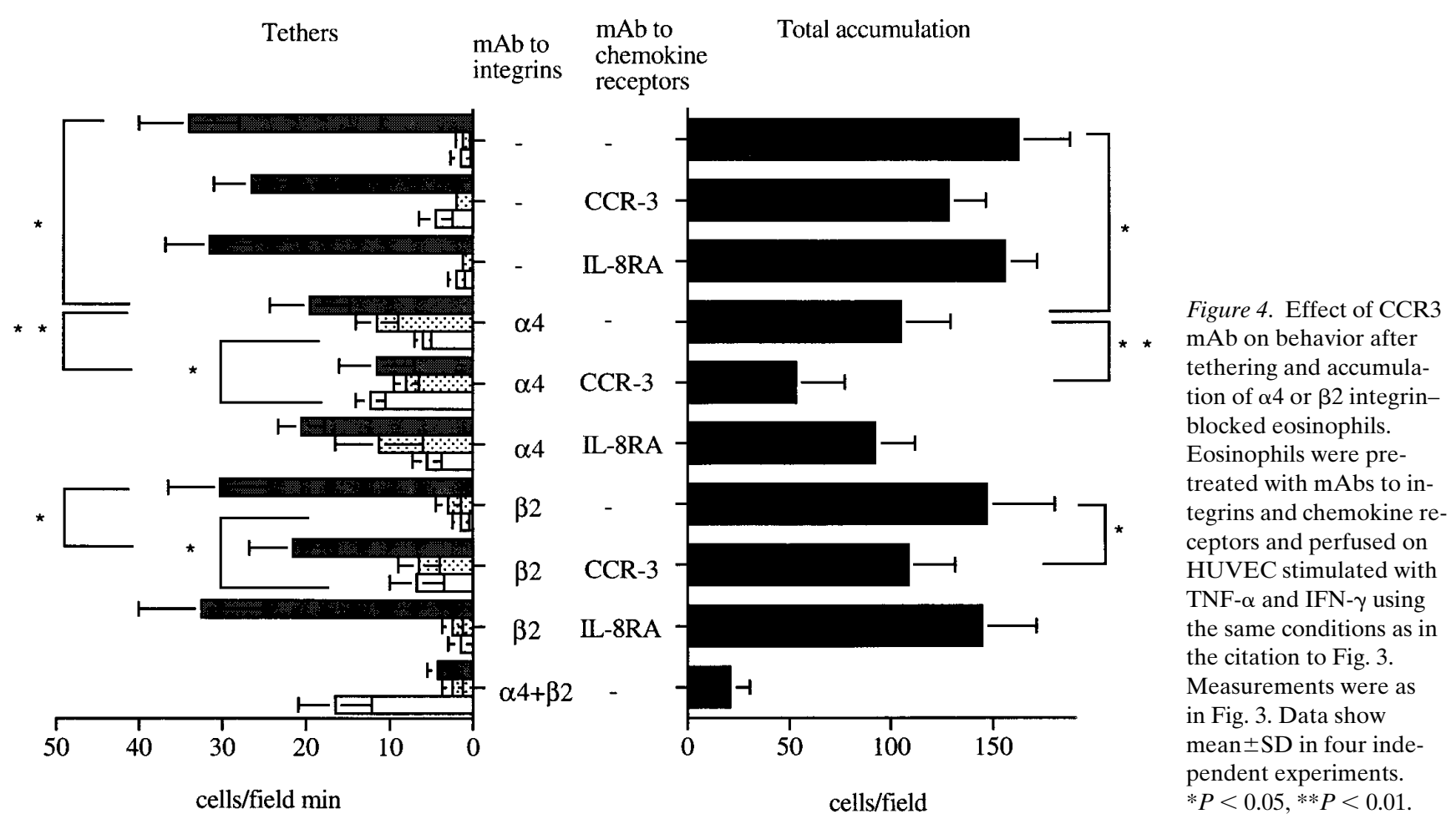


Tethers Total accumulation

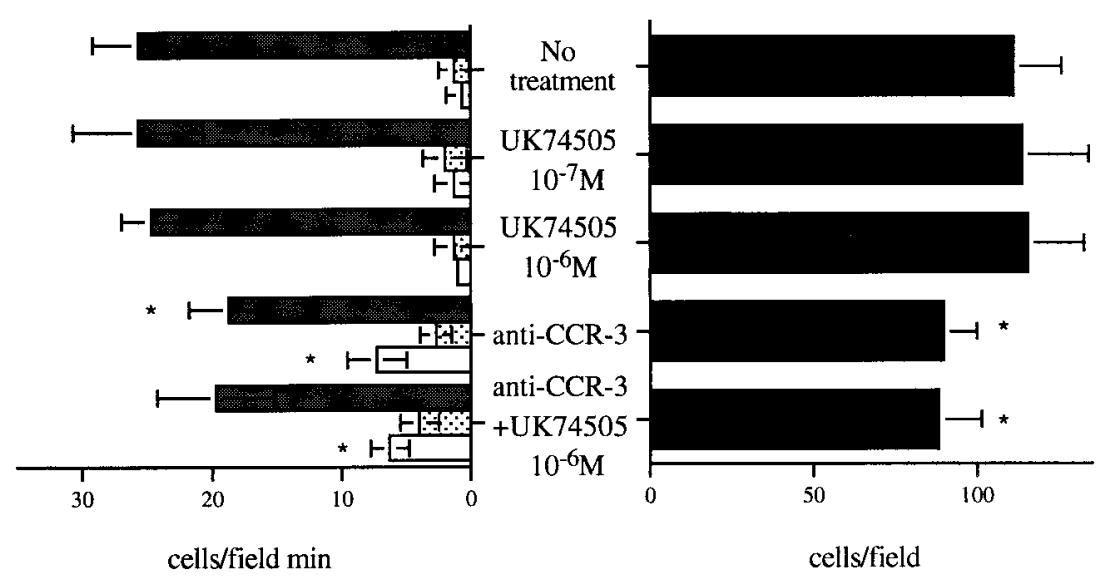

B

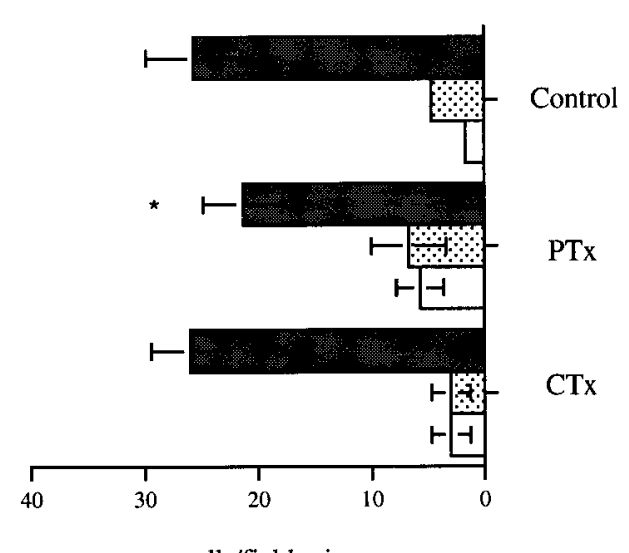

cells/field $\mathrm{min}$

Tethers

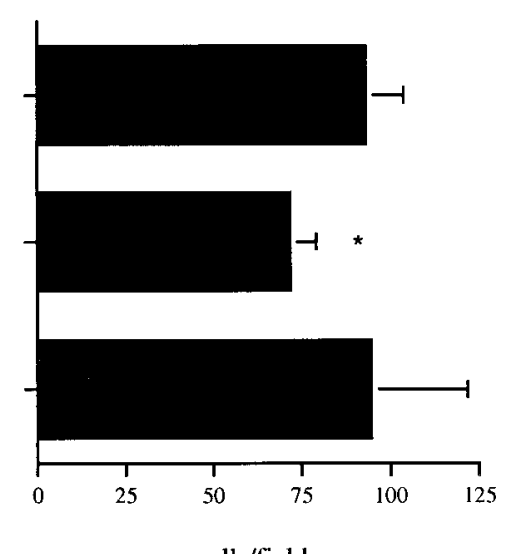

cells/field
Figure 5. Effect of PAF antagonist or PTx on eosinophil interaction with activated HUVEC in shear flow. $(A)$ Eosinophils $\left(10^{6}\right)$ in $0.1 \mathrm{ml}$ of HBSS plus $10 \mathrm{nM}$ Hepes were incubated with UK-74505 at a final concentration of $10^{-6}$ or $10^{-7} \mathrm{M}$ for $30 \mathrm{~min}$ with or without CCR3 $\mathrm{mAb}$, diluted in $1.0 \mathrm{ml}$ of assay medium, and perfused on HUVEC monolayers stimulated with $100 \mathrm{U} / \mathrm{ml}$ of TNF- $\alpha$ and IFN- $\gamma$ for $24 \mathrm{~h}$. (B) Eosinophils were preincubated with PTx or CTx at a final concentration of $250 \mathrm{ng} / \mathrm{ml}$ for $2 \mathrm{~h}$ at $37^{\circ} \mathrm{C}$. Perfusion was for $3 \mathrm{~min}$ at $1.5 \mathrm{dyn} / \mathrm{cm}^{2}$, and interaction was measured as in the citation to Fig. 3. Data show mean \pm SD of three different experiments. $* P<0.05$. all experimental conditions, IL-8RA mAb had no inhibitory effect (Fig. 4).

Effect of platelet-activating factor $(P A F)$ antagonist or PTx on eosinophil arrest and accumulation on activated HUVEC. In the same experimental system, we examined the effect of PAF antagonist or PTx. UK-74505, one of the most potent PAF antagonists $(43,44)$, at either $10^{-7}$ or $10^{-6} \mathrm{M}$ concentration showed no significant effect on eosinophil tethering, arrest, and accumulation whether used alone or together with CCR3 mAb (Fig. $5 A$ ). PTx has been shown previously to block CCR3-dependent eosinophil responses $(18,19)$. 2-h incubation with PTx but not with CTx significantly decreased eosinophil arrest and accumulation, by $17 \pm 1.2 \%(P<0.05$, $n=4)$ and $23 \pm 3.4 \%(P<0.05, n=4)$, respectively (Fig. $5 B)$. However, the amount of inhibition with PTx was the same as with CCR3 mAb.

\section{Discussion}

In this study, we examined how chemoattractants produced in situ affect eosinophil adhesive interactions with endothelial cells in shear flow using a function-blocking mAb to CCR3. Our data show that TNF- $\alpha$ and IFN- $\gamma$-stimulated HUVEC produced chemoattractants for eosinophils, consistent with a previous report demonstrating RANTES production by cytokine-stimulated HUVEC (45). Furthermore, supernatant from activated HUVEC enhanced eosinophil binding to immobilized ICAM-1 and VCAM-1 in a 3-min static assay, suggesting that chemokines can activate both $\alpha 4$ and $\beta 2$ integrins within minutes. Importantly, stimulation of chemotaxis and adhesion by eosinophils was abrogated completely by pretreatment with the CCR3 mAb. These results confirm inhibition of responses to specific chemokines in a previous study (28), and further suggest that even if the activated HUVEC produce some other unknown chemoattractants, their effects on eosinophils are entirely through CCR3. This validated the use of CCR3 mAb for evaluation of the effect of chemoattractants released by activated HUVEC on eosinophil interactions in shear flow.

As reported for TNF- $\alpha$-activated HUVEC (42), most tethered eosinophils did not roll, but arrested abruptly on TNF- $\alpha$ and IFN- $\gamma$-activated HUVEC monolayers under physiological shear stress. Treatment with CCR3 mAb partially but signifi- 
cantly decreased eosinophil accumulation. Videotape analysis revealed that the treatment did not affect the total number of tethered eosinophils, but inhibited conversion of tethered cells to firmly adherent cells and thus increased the percentage of cells that detached from the monolayer within the next $30 \mathrm{~s}$ after tethering. This indicates that the HUVEC-derived chemokines enhance eosinophil adhesiveness within seconds and thus prevent the detachment of eosinophils tethered on the HUVEC surface. Detachment of the tethered cells was observed mostly within the $30 \mathrm{~s}$ immediately after tethering, and cells that remained adherent beyond $30 \mathrm{~s}$ rarely rolled or detached thereafter. This is not surprising, because chemoattractant stimulation often shows peak responses in $\mathrm{Ca}^{2+}$ influx or actin polymerization within $30 \mathrm{~s}(11,46-48)$. However, the majority of the anti-CCR3-treated eosinophils still showed immediate arrest, with only a few rolling cells. PTx-treated eosinophils were similarly capable of almost immediate arrest after tethering, with little intervening rolling.

This behavior may be attributed to the functional expression of $\alpha 4$ integrins in eosinophils. Consistent with our previous findings (42), eosinophil arrest on activated HUVEC was dependent mostly on $\alpha 4$ integrin and only partially on $\beta 2$ integrin. In the presence of $\alpha 4 \mathrm{mAb}$, approximately half of eosinophil arrest and accumulation was abrogated by CCR3 $\mathrm{mAb}$. By contrast, CCR3 mAb had less effect on $\beta 2$ integrinblocked eosinophils, and inhibited to almost the same level as when no antiintegrin $\mathrm{mAb}$ was used. Moreover, comparing groups that were all treated with $\mathrm{CCR} 3 \mathrm{mAb}$, the addition of $\alpha 4 \mathrm{mAb}$ reduced accumulation by half $(P<0.05, n=4)$, but $\beta 2 \mathrm{mAb}$ had very little effect $(P>0.1, n=4)$. These findings imply that $\alpha 4$ integrins on eosinophils have considerable potential to mediate eosinophil arrest on activated HUVEC, even without exposure to chemoattractants. This may make the effect of CCR3 mAb less prominent in flow experiments. Indeed, $\alpha 4$ integrin has been shown to support leukocyte adhesion even in the presence of shear stress $(49,50)$, and to be mainly responsible for monocyte or lymphocyte arrest on endothelial cells under physiological shear conditions $(51,52)$. In contrast, $\beta 2$ integrins are unable to support leukocyte adhesion in physiological shear flow without the participation of other adhesion molecules to mediate tethering and rolling (3). The functional difference between $\alpha 4$ and $\beta 2$ integrins may also explain the higher binding of unstimulated eosinophils to VCAM-1 than to ICAM-1 in static assays.

The lack of complete inhibition of adhesion in flow to stimulated HUVEC by CCR3 mAb, even in the presence of $\alpha 4$ $\mathrm{mAb}$, contrasted with results in chemotaxis and static adhesion assays. This indicates that the role of chemoattractants in eosinophil arrest on endothelium may be less important than in the following transmigration step, and that other mechanisms may be important in arrest. An alternative mechanism for activation of integrins is through stimulation by PAF, because PAF has been shown to be produced by TNF- $\alpha-$ stimulated HUVEC (53) and to use a receptor distinct from CCR3 (54). In static experiments, PAF has been found to stimulate neutrophil $\beta 2$ integrins in cooperation with $\mathrm{P}$-selectin $(55,56)$. Furthermore, PAF produced from TNF- $\alpha-$ stimulated HUVEC is mostly surface associated and is not released as the soluble factor (53). A PAF antagonist partially reduced neutrophil attachment to TNF- $\alpha-$ or thrombin-stimulated HUVEC in flow (57). Therefore, we perfused eosinophils pretreated with a PAF receptor antagonist, UK-74505, on the activated
HUVEC under the same shear conditions. However, the antagonist, at either known optimal or higher concentrations, showed no significant effect on eosinophil arrest or accumulation. The reason for this discrepancy between eosinophils and neutrophils is not clear, but might be caused by the differential effects of PAF on activating $\alpha 4$ or $\beta 2$ integrins, since there are some reports suggesting that PAF can increase eosinophil binding to ICAM-1 (58) and mucosal addressin cell adhesion molecule 1 (59) but not to VCAM-1 (59). To test whether activation might occur through yet other $\mathrm{G}$ protein-coupled receptors on eosinophils, we examined the effect of PTx treatment. PTx treatment partially decreased eosinophil arrest and accumulation; however, the inhibitory effect did not exceed that of anti-CCR3 mAb. From these results, it appears that PAF or other chemoattractants that might be retained on the HUVEC surface and do not bind CCR3 have little role in eosinophil arrest on endothelium.

It has been proposed that selectin-mediated interactions can trigger integrin activation. Several studies have shown that binding to E-selectin (60-62) or cross-linking of L-selectin (63, 64) enhances $\beta 2$ integrin-mediated adhesion, although there is no evidence that $\mathrm{P}$-selectin directly activates the $\beta 2$ integrin. In eosinophils, tethering is dependent mainly on P-selectin and partially on L-selectin but not on E-selectin $(42,65,66)$. We have observed that blockade of P- or L-selectin by mAbs partially decreased the tethering efficiency of eosinophils but did not affect posttethering behavior (42). This suggests that selectin-mediated adhesion is not responsible for integrin activation and eosinophil arrest on activated HUVEC.

In summary, chemokines produced by TNF- $\alpha$ and IFN$\gamma$-stimulated endothelium can act through CCR3 to enhance the avidity of both $\alpha 4$ and $\beta 2$ integrins of eosinophils. Adhesion strengthening occurs within seconds and augments eosinophil accumulation in shear flow by converting transiently tethered cells to arrested cells. Although the role of chemokines in arrest and accumulation of eosinophils on stimulated endothelium appears to be less prominent than in transmigration, our study is the first to demonstrate that locally produced chemokines are actually involved in leukocyte arrest and accumulation on endothelium in shear flow.

\section{Acknowledgments}

This work was supported by grant HL-48675 from the National Institutes of Health.

\section{References}

1. Springer, T.A. 1994. Traffic signals for lymphocyte recirculation and leukocyte emigration: the multi-step paradigm. Cell. 76:301-314.

2. Butcher, E.C. 1991. Leukocyte-endothelial cell recognition: three (or more) steps to specificity and diversity. Cell. 67:1033-1036.

3. Lawrence, M.B., and T.A. Springer. 1991. Leukocytes roll on a selectin at physiologic flow rates: distinction from and prerequisite for adhesion through integrins. Cell. 65:859-873.

4. Honda, S., J.J. Campbell, D.P. Andrew, B. Engelhardt, B.A. Butcher R.A. Warnock, R.D. Ye, and E.C. Butcher. 1994. Ligand-induced adhesion to activated endothelium and to vascular cell adhesion molecule- 1 in lymphocytes transfected with the N-formyl peptide receptor. J. Immunol. 152:4026-4035.

5. McLellan, A.D., R.V. Sorg, L.A. Williams, and D.N.J. Hart. 1996. Human dendritic cells activate T lymphocytes via a CD40 ligand-dependent pathway. Eur. J. Immunol. 26:1204-1210.

6. Rot, A. 1992. Endothelial cell binding of NAP-1/IL-8: role in neutrophil emigration. Immunol. Today. 13:291-294.

7. Tanaka, Y., D.H. Adams, S. Hubscher, H. Hirano, U. Siebenlist, and S Shaw. 1993. T-cell adhesion induced by proteoglycan-immobilized cytokine 
MIP-1ß. Nature. 361:79-82

8. Gleich, G.J., and C.R. Adolphson. 1986. The eosinophilic leukocyte: structure and function. Adv. Immunol. 39:177-253.

9. Bousquet, J., P. Chanez, J.Y. Lacoste, G. Barneon, N. Ghavanian, I. Enander, P. Venge, S. Ahlstedt, J. Simony-Lafontaine, P. Godard, and F.-B. Michel. 1990. Eosinophilic inflammation in asthma. N. Engl. J. Med. 323:10331039.

10. Kameyoshi, Y., A. Dörschner, A.I. Mallet, E. Christophers, and J.-M. Schröder. 1992. Cytokine RANTES released by thrombin-stimulated platelets is a potent attractant for human eosinophils. J. Exp. Med. 176:587-592.

11. Rot, A., M. Krieger, T. Brunner, S.C. Bischoff, T.J. Schall, and C.A. Dahinden. 1992. RANTES and macrophage inflammatory protein $1 \alpha$ induce the migration and activation of normal human eosinophil granulocytes. J. Exp. Med. 176:1489-1495.

12. Ebisawa, M. T. Yamada, C. Bickel, D. Klunk, and R.P. Schleimer. 1994. Eosinophil transendothelial migration induced by cytokines: III. Effect of the chemokine RANTES. J. Immunol. 153:2153-2160.

13. Noso, N., P. Proost, J. Van Damme, and J.-M. Schröder. 1994. Human monocyte chemotactic proteins-2 and 3 (MCP-2 and MCP-3) attract human eosinophils and desensitize the chemotactic responses towards RANTES. Biochem. Biophys. Res. Commun. 200:1470-1476.

14. Dahinden, C.A., T. Geiser, T. Brunner, V. von Tscharner, D. Caput, P. Ferrara, A. Minty, and M. Baggiolini. 1994. Monocyte chemotactic protein 3 is a most effective basophil- and eosinophil-activating chemokine. J. Exp. Med. 179:751-756.

15. Uguccioni, M., P. Loetscher, U. Forssmann, B. Dewald, H. Li, S.H. Lima, Y. Li, B. Kreider, G. Garotta, M. Thelen, and M. Baggiolini. 1996. Monocyte chemotactic protein 4 (MCP-4), a novel structural and functional analogue of MCP-3 and eotaxin. J. Exp. Med. 183:2379-2384.

16. Rothenberg, M.E., A.D. Luster, and P. Leder. 1995. Murine eotaxin: an eosinophil chemoattractant inducible in endothelial cells and in interleukin 4-induced tumor suppression. Proc. Natl. Acad. Sci. USA. 92:8960-8964.

17. Ponath, P.D., S. Qin, D.J. Ringler, I. Clark-Lewis, J. Wang, N. Kassam, H. Smith, X. Shi, J.-A. Gonzalo, W. Newman, et al. 1996. Cloning of the human eosinophil chemoattractant, eotaxin. Expression, receptor binding, and functional properties suggest a mechanism for the selective recruitment of eosinophils. J. Clin. Invest. 97:604-612.

18. Tenscher, K., B. Metzner, E. Schopf, J. Norgauer, and W. Czech. 1996. Recombinant human eotaxin induces oxygen radical production, $\mathrm{Ca}^{2+}$-mobilization, actin reorganization, and CD11b upregulation in human eosinophils via a pertussis toxin-sensitive heterotrimeric guanine nucleotide-binding protein. Blood. 88:3195-3199.

19. Elsner, J., R. Hochstetter, D. Kimmig, and A. Kapp. 1996. Human eotaxin represents a potent activator of the respiratory burst of human eosinophils. Eur. J. Immunol. 26:1919-1925.

20. Forssmann, U., M. Uguccioni, P. Loetscher, C.A. Dahinden, H. Langen, M. Thelen, and M. Baggiolini. 1997. Eotaxin-2, a novel CC chemokine that is selective for the chemokine receptor CCR3, and acts like eotaxin on human eosinophil and basophil leukocytes. J. Exp. Med. 185:2171-2176.

21. Weber, C., J. Kitayama, and T.A. Springer. 1996. Differential regulation of $\beta 1$ - and $\beta 2$-integrin avidity by chemoattractants in eosinophils. Proc. Natl. Acad. Sci. USA. 93:10939-10944.

22. Kita, H., and G.J. Gleich. 1996. Chemokines active on eosinophils: potential roles in allergic inflammation. J. Exp. Med. 183:2421-2426.

23. Mackay, C.R. 1996. Chemokine receptors and T cell chemotaxis. J. Exp. Med. 184:799-802.

24. Baggiolini, M., B. Dewald, and B. Moser. 1994. Interleukin-8 and related chemotactic cytokines- $\mathrm{CXC}$ and $\mathrm{CC}$ chemokines. Adv. Immunol. 55: 97-179.

25. Baggiolini, M., and C.A. Dahinden. 1994. CC chemokines in allergic inflammation. Immunol. Today. 15:127-133.

26. Ponath, P.D., S. Qin, T.W. Post, J. Wang, L. Wu, N.P. Gerard, W. Newman, C. Gerard, and C.R. Mackay. 1996. Molecular cloning and characterization of a human eotaxin receptor expressed selectively on eosinophils. J. Exp. Med. 183:2437-2448.

27. Daugherty, B.L., S.J. Siciliano, J.A. DeMartino, L. Malkowitz, A. Sirotina, and M.S. Springer. 1996. Cloning, expression, and characterization of the human eosinophil eotaxin receptor. J. Exp. Med. 183:2349-2354.

28. Heath, H., S. Qin, P. Rao, L. Wu, G. LaRosa, N. Kassam, P.D. Ponath, and C.R. Mackay. 1997. Chemokine receptor usage by human eosinophils. The importance of CCR3 demonstrated using an antagonistic monoclonal antibody. J. Clin. Invest. 99:178-184.

29. Wu, L., N. Ruffing, X. Shi, W. Newman, D. Soler, C.R. Mackay, and S. Qin. 1996. Discrete steps in binding and signaling of interleukin-8 with its receptor. J. Biol. Chem. 271:31202-31209.

30. Sanchez-Madrid, F., J. Nagy, E. Robbins, P. Simon, and T.A. Springer. 1983. A human leukocyte differentiation antigen family with distinct alpha subunits and a common beta subunit: the lymphocyte function-associated antigen (LFA-1), the C3bi complement receptor (OKM1/Mac-1), and the p150,95 molecule. J. Exp. Med. 158:1785-1803.

31. Marlin, S.D., D.E. Staunton, T.A. Springer, C. Stratowa, W. Sommergruber, and V. Merluzzi. 1990. A soluble form of intercellular adhesion mole- cule-1 inhibits rhinovirus infection. Nature. 344:70-72.

32. Pepinsky, B., C. Hession, L.-L. Chen, P. Moy, L. Burkly, A. Jakubowski, E.P. Chow, C. Benjamin, G. Chi-Rosso, S. Luhowskyj, and R. Lobb. 1992. Structure/function studies on vascular cell adhesion molecule-1. J. Biol. Chem. 267:17820-17826.

33. Hansel, T.T., J.D. Pound, D. Pilling, G.D. Kitas, M. Salmon, T.A. Gentle, S.S. Lee, and R.A. Thompson. 1989. Purification of human blood eosinophils by negative selection using immunomagnetic beads. J. Immunol. Methods. 122:97-103.

34. Gimbrone, M.A., Jr. 1976. Culture of vascular endothelium. Prog. Hemostasis Thromb. 3:1-28.

35. Roth, S.J., M.W. Carr, S.S. Rose, and T.A. Springer. 1995. Characterization of transendothelial chemotaxis of T lymphocytes. J. Immunol. Methods. 100:97-116.

36. Jones, D. A., O. Abbassi, L.V. McIntire, R.P. McEver, and C.W. Smith. 1993. P-selectin mediates neutrophil rolling on histamine-stimulated endothelial cells. Biophys. J. 65:1560-1569.

37. Lawrence, M.B., and T.A. Springer. 1993. Neutrophils roll on E-selectin. J. Immunol. 151:6338-6346.

38. Weller, P.F., T.H. Rand, S.E. Goelz, G. Chi-Rosso, and R.R. Lobb. 1991. Human eosinophil adherence to vascular endothelium mediated by binding to vascular cell adhesion molecule 1 and endothelial leukocyte adhesion molecule 1. Proc. Natl. Acad. Sci. USA. 88:7430-7433.

39. Dobrina, A., R. Menegazzi, T.M. Carlos, E. Nardon, R. Cramer, T. Zacchi, J.M. Harlan, and P. Patriarca. 1991. Mechanisms of eosinophil adherence to cultured vascular endothelial cells. Eosinophils bind to the cytokine-induced endothelial ligand vascular cell adhesion molecule- 1 via the very late activation antigen-4 integrin receptor. J. Clin. Invest. 88:20-26.

40. Bochner, B.S., F.W. Luscinskas, M.A. Gimbrone, Jr., W. Newman, S.A. Sterbinsky, C.P. Derse-Anthony, D. Klunk, and R.P. Schleimer. 1991. Adhesion of human basophils, eosinophils, and neutrophils to interleukin 1-activated human vascular endothelial cells: contributions of endothelial cell adhesion molecules. J. Exp. Med. 173:1553-1556.

41. Walsh, G.M., J.-J. Mermod, A. Hartnell, A.B. Kay, and A.J. Wardlaw. 1991. Human eosinophil, but not neutrophil, adherence to IL-1-stimulated human umbilical vascular endothelial cell is $\alpha_{4} \beta_{1}$ (very late antigen-4) dependent J. Immunol. 146:3419-3423.

42. Kitayama, J., M.W. Carr, S.J. Roth, J. Buccola, and T.A. Springer. 1997. Contrasting responses to multiple chemotactic stimuli in transendothelial migration. J. Immunol. 158:2340-2349.

43. Pons, F., A.G. Rossi, K.E. Norman, T.J. Williams, and S. Nourshargh. 1993. Role of platelet-activating factor (PAF) in platelet accumulation in rabbit skin: affect of the novel long-acting PAF antagonist, UK-74,505. Br. J. Pharmacol. 109:234-242.

44. Sanz, M.J., V.B. Weg, D.T. Walsh, T.J. Williams, and S. Nourshargh. 1994. Differential effects of the PAF receptor antagonist UK-74,505 on neutrophil and eosinophil accumulation in guinea-pig skin. Br. J. Pharmacol. 113:513-521.

45. Marfaing-Koka, A., O. Devergne, G. Gorgone, A. Portier, T.J. Schall, P. Galanaud, and D. Emilie. 1995. Regulation of the production of the RANTES chemokine by endothelial cells. J. Immunol. 154:1870-1878.

46. Baggiolini, M., A. Walz, and S.L. Kunkel. 1989. Neutrophil-activating peptide-1/interleukin 8 , a novel cytokine that activates neutrophils. J. Clin. Invest. 84:1045-1049.

47. Detmers, P.A., D.E. Powell, A. Walz, I. Clark-Lewis, M. Baggiolini, and Z.A. Cohn. 1991. Differential effects of neutrophil-activating peptide 1/IL-8 and its homologues on leukocyte adhesion and phagocytosis. J. Immunol. 147: 4211-4217.

48. Westlin, W.F., J.-M. Kiely, and M.A. Gimbrone. 1992. Interleukin-8 induces changes in human neutrophil actin conformation and distribution: relationship to inhibition of adhesion to cytokine-activated endothelium. J. Leukocyte Biol. 52:43-51.

49. Berlin, C., R.F. Bargatze, U.H. von Andrian, M.C. Szabo, S.R. Hasslen, R.D. Nelson, E.L. Berg, S.L. Erlandsen, and E.C. Butcher. 1995. $\alpha 4$ integrins mediate lymphocyte attachment and rolling under physiologic flow. Cell. 80: 413-422.

50. Alon, R., P.D. Kassner, M.W. Carr, E.B. Finger, M.E. Hemler, and T.A. Springer. 1995. The integrin VLA-4 supports tethering and rolling in flow on VCAM-1.J. Cell Biol. 128:1243-1253.

51. Luscinskas, F.W., G.S. Kansas, H. Ding, P. Pizcueta, B.E. Schleiffenbaum, T.F. Tedder, and M.A. Gimbrone, Jr. 1994. Monocyte rolling, arrest and spreading on IL-4-activated vascular endothelium under flow is mediated via sequential action of L-selectin, $\beta_{1}$-integrins, and $\beta_{2}$-integrins. J. Cell Biol. 125: 1417-1427.

52. Luscinskas, F.W., H. Ding, and A.H. Lichtman. 1995. P-selectin and vascular cell adhesion molecule 1 mediate rolling and arrest, respectively, of CD4 ${ }^{+}$ $\mathrm{T}$ lymphocytes on tumor necrosis factor $\alpha$-activated vascular endothelium under flow. J. Exp. Med. 181:1179-1186.

53. Camussi, G., F. Bussolino, G. Salvidio, and C. Baglioni. 1987. Tumor necrosis factor/cachectin stimulates peritoneal macrophages, polymorphonuclear neutrophils, and vascular endothelial cells to synthesize and release plateletactivating factor. J. Exp. Med. 166:1390-1404.

54. Honda, Z., M. Nakamura, I. Miki, M. Minami, T. Watanabe, Y. Seyama, 
H. Okado, H. Toh, K. Ito, T. Miyamoto, and T. Shimizu. 1991. Cloning by functional expression of platelet-activating factor receptor from guinea-pig lung. Nature. 349:342-346.

55. Zimmerman, G.A., T.M. McIntyre, M. Mehra, and S.M. Prescott. 1990. Endothelial cell-associated platelet-activating factor: a novel mechanism for signaling intercellular adhesion. J. Cell Biol. 110:529-540.

56. Lorant, D.E., K.D. Patel, T.M. McIntyre, R.P. McEver, S.M. Prescott, and G.A. Zimmerman. 1991. Coexpression of GMP-140 and PAF by endothelium stimulated by histamine or thrombin: a juxtacrine system for adhesion and activation of neutrophils. J. Cell Biol. 115:223-234.

57. Macconi, D., M. Foppolo, S. Paris, M. Noris, S. Aiello, G. Remuzzi, and A. Remuzzi. 1995. PAF mediates neutrophil adhesion to thrombin or TNFstimulated endothelial cells under shear stress. Am. J. Physiol. 269:C42-C47.

58. Kimani, G., M.G. Tonnesen, and P.M. Henson. 1988. Stimulation of eosinophil adherence to human vascular endothelial cells in vitro by plateletactivating factor. J. Immunol. 140:3161-3166.

59. Walsh, G.M., F.A. Symon, A.I. Lazarovits, and A.J. Wardlaw. 1996. Integrin $\alpha_{4} \beta_{7}$ mediates human eosinophil interaction with MAdCAM-1, VCAM-1 and fibronectin. Immunology. 89:112-119.

60. Lo, S.K., S. Lee, R.A. Ramos, R. Lobb, M. Rosa, G. Chi-Rosso, and S.D. Wright. 1991. Endothelial-leukocyte adhesion molecule 1 stimulates the adhesive activity of leukocyte integrin CR3 (CD11b/CD18, Mac-1, $\alpha_{m} \beta_{2}$ ) on human neutrophils. J. Exp. Med. 173:1493-1500.

61. Kuijpers, T.W., B.C. Hakkert, M. Hoogerwerf, J.F. M. Leeuwenberg, and D. Roos. 1991. Role of endothelial leukocyte adhesion molecule-1 and platelet-activating factor in neutrophil adherence to IL-1-prestimulated endothelial cells. Endothelial leukocyte adhesion molecule-1-mediated CD18 activation. J. Immunol. 147:1369-1376.

62. Kuijpers, T.W., M. Hoogerwerf, L.J.W. van der Laan, G. Nagel, C.E. Van Der Schoot, F. Grunert, and D. Roos. 1992. CD66 nonspecific cross-reacting antigens are involved in neutrophil adherence to cytokine-activated endothelial cells. J. Cell Biol. 118:457-466.

63. Simon, S.I., A.R. Burns, A.D. Taylor, P.K. Gopalan, E.B. Lynam, L.A. Sklar, and C.W. Smith. 1995. L-selectin (CD62L) cross-linking signals neutrophil adhesive functions via the Mac-1 (CD11b/CD18) $\beta_{2}$-integrin. J. Immunol. 155:1502-1514.

64. Gopalan, P.K., C.W. Smith, H. Lu, E.L. Berg, L.V. McIntire, and S.I. Simon. 1997. Neutrophil CD18-dependent arrest on intercellular adhesion molecule 1 (ICAM-1) in shear flow can be activated through L-selectin. J. Immunol. 158:367-375.

65. Sriramarao, P., C.R. Norton, P. Borgstrom, R.G. DiScipio, B.A Wolitzky, and D.H. Broide. 1996. E-selectin preferentially supports neutrophil but not eosinophil rolling under conditions of flow in vitro and in vivo. J. Immunol. $157: 4672-4680$.

66. Henriques, G.M.O., J.M. Miotla, R.S.B. Cordeiro, B.A. Wolitzky, S.T. Woolley, and P.G. Hellewell. 1996. Selectins mediate eosinophil recruitment in vivo: a comparison with their role in neutrophil influx. Blood. 87:5297-5304. 